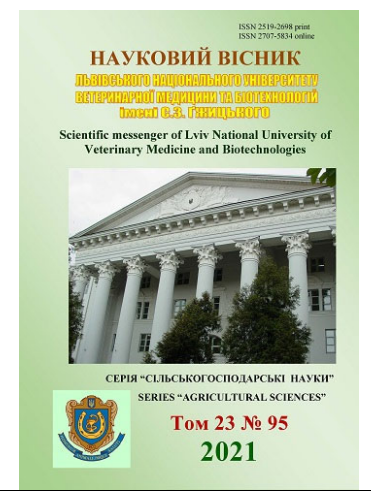

Науковий вісник Дьвівського національного університету ветеринарної медицини та біотехнологій імені С.3. Гжицького. Серія: Сільськогосподарські науки

\author{
Scientific Messenger of Lviv National University \\ of Veterinary Medicine and Biotechnologies. \\ Series: Agricultural sciences
}

doi: 10.32718/nvlvet-a9520

https://nvlvet.com.ua/index.php/agriculture

UDC 638.1:591.615

\title{
Influence of early spring feeding on the development of bee families in the natural lands of Polissya
}

O. M. Sichenko

Polissia National University, Zhytomyr, Ukraine

Article info

Received 21.06.2021

Received in revised form 26.07.2021

Accepted 27.07.2021

Polissia National University, Stary Boulevard, 7, Zhytomyr, 10008, Ukraine.

Tel.: +38-097-965-77-73

E-mail: Sichenkoo@gmail.com
Sichenko, O. M. (2021). Influence of early spring feeding on the development of bee families in the natural lands of Polissya. Scientific Messenger of Lviv National University of Veterinary Medicine and Biotechnologies. Series: Agricultural sciences, 23(95), 136-140. doi: 10.32718/nvlvet-a9520

To ensure intensive early spring development of bee colonies in the natural lands of Polissya Zhytomyr region in the winter-spring period it is necessary to feed stimulating food. Therefore, the aim of the work is to study the influence of spring feeding with sugar-honey dough on the development and honey productivity of bee families of Ukrainian breed in conditions of clean and radioactively contaminated natural lands of Zhytomyr Polissya. The influence of feeding bee colonies with sugar-honey dough (powdered sugar, centrifuged honey, water) using pure and radioactively contaminated honey on the intensity of development and honey productivity was studied. To do this, two groups were created with experimental families of Ukrainian bee breeds, selected on the principle of analogs, one of which was in a radioactively clean area, and the other in radioactively contaminated soils $137 \mathrm{Cs}$ within $15 \mathrm{Ki} / \mathrm{km}^{2}$ and above. A comparative assessment of the early spring development of families was made: from March 16 to May 20, with an interval of 21 days, the number of open and sealed brood, egg production of queens during the honey harvest season was determined. Honey productivity at the honey harvest from natural lands was determined by the amount of honey obtained in spring and summer. Early spring feeding with sugar-honey dough promotes intensive development of families, and the content of radioactively contaminated honey does not have a negative impact on their development. After the end of the season of honey collection from natural lands, bee families of Ukrainian breed, both in the radioactively contaminated and clean zone, had a medium strength and could successfully overwinter.

Key words: sugar-honey dough, the strength of the bee colony, the number of brood, egg production of the uterus.

\section{Вплив ранньовесняної підгодівлі на розвиток бджолиних сімей в умовах природних угідь Полісся}

\author{
О. М. Січенко
}

Поліський наџіональний університет, м. Житомир, Украӥна

\footnotetext{
Для забезпечення інтенсивного ранньовесняного розвитку бджолиних сімей в умовах природних угідь Полісся Житомириини в зимово-весняний період необхідно згодовувати стимулюючий корм. Тому метою роботи є вивчити вплив весняної підгодівлі иукровомедовим тістом на розвиток та медову продуктивність бджолиних сімей украӥнської породи в умовах чистих та радіоактивно забруднених природних угідь Житомирського Полісся. Під час досліджень вивчено вплив підгодівлі бджолиних сімей иукрово-медовим тістом (иукрова пудра, центрифужний мед, вода) з використанням чистого та радіоактивно забрудненого меду на інтенсивність розвитку та медову продуктивність. Для иього створили дві групи з піддослідними сім'ями украӥнської породи бджіл, підібраними за принципом аналогів, одна з яких знаходилася на радіоактивно чистій території, а друга в умовах радіоактивно забруднених грунтах ${ }^{137} \mathrm{Cs}$ в межах $15 \mathrm{Ki} / \mathrm{kм}^{2}$ і вище. Здійснили порівняльну оцінку ранньовесняного розвитку сімей: 316 березня по 20 травня з інтервалом у 21 день визначали кількість відкритого та запечатаного розплоду, яйценосність маток протягом сезону медозбору. Медову продуктивність на медозборі з природних угідь визначали за обсягом отриманого меду у весняно- літній, та осінній періоди. Ранньовесняна підгодівля иукрово-медовим тістом сприяє інтенсивному розвитку сімей, а вміст радіоактивно забрудненого меду не чинить негати-
} 
вного впливу на їх розвиток. Після закінчення сезону медозбору з природних угідь, бджолині сім ’ї української породи, як у радіоактивно забрудненій так і чистій зоні, мали середню силу і могли успішно перезимувати.

Ключові слова: иукрово-медове тісто, сила бджолиної сім $\dddot{\imath}$, кількість розплоду, яйценосність матки.

\section{Вступ}

Полісся України це регіон, який має розвинуту галузь бджільництва завдяки своєму розташуванню у сприятливих природно-кліматичних умовах 3 достатньою кількістю медоносів природних фітоценозів (Verbel'chuk et al., 2017; Byel's'ka, 2020).

Основні фактори, які впливають на продуктивність і виживання сім’і - біорізноманітна кормова база, кліматичні умови та технологічні заходи для підтримання сили бджолиної сім’ї, а також порода бджіл, їх генетичні особливості, віковий стан матки (Polishchuk, 2001; Papchenko, 2013). Хоча медоносні бджоли збирають нектар i пилок у широкому діапазоні кліматичних умов, вони зменшують свою льотну діяльність під час несприятливих погодних умов (Brovarskyi \& Bahrii, 1995; Andjelkovic et al., 2011). Науковці підтверджують, що багаті нектаром та пилком дерева та кущі зменшують негативний вплив гарячої, сухої, вітряної погоди (Abdulaziz, 2020). Також різні породи бджіл порізному реагують на такі обставини. Але, особини місцевої породи бджіл завжди краще пристосовані і мають більшу продуктивність на зборі з місцевих природних угідь (Pankiw et al., 2002).

Нектароносний та пилконосний сезон української медоносної бджоли на Поліссі починається 3 початком цвітіння верби козячої, що припадає на початок квітня. Збір нектару та пилку у цей період ускладнюється через низькі добові температури та часті опади. Але, частка нектару з весняних медоносів Житомирського Полісся у загальному річному виробництві меду 3 природних угідь становить до $40 \%$. На літо припадає $25 \%$, решта $35 \%$ запасу нектару - це осінні медоноси (Sichenko et al., 2021). У таких умовах посилений весняний розвиток сімей є найбільш доцільним, щоб бджоли могли найповніше використовувати ранній весняний пилковий та медовий запас (Puškadija et al., 2017). Сила бджолиних сімей є одним із ключових факторів, що впливає на їх продуктивність. Приблизно $60 \%$ бджіл із сильних сімей працює на льотних роботах при медозборі, а у слабких - лише до $20 \%$. (Polishchuk, 2014). Зимові запаси корму та пилку у вуликах відіграють важливу роль у весняний період, коли сім’ї починають вирощувати розплід, а пилок не надходить (Di Pasquale et al., 2013). Достатня та збалансована їжа забезпечує нормальний розвиток здорових бджолиних сімей (Brodschneider \& Crailsheim, 2010), а іiї недостатня кількість у вулику може обмежити розвиток сім’ї (Mattila \& Otis, 2006), особливо навесні, коли нарощування кількості робочих бджіл перебуває у найбільш чутливій стадії (Khoury et al., 2013). Тому, у весняний період, коли свіжий нектар та пилок поступає нерівномірно, інтенсивно нарощувати кількість бджіл-збирачок, можливо тільки при наявності у вулику достатньої кількості вуглеводистих та білкових кормів (Mattila \& Otis, 2006; Khoury et al., 2013; Di Pasquale et al., 2013; Abdulaziz, 2020). Запро- понований нами спосіб підгодівлі дозволяє застосовувати радіоактивно-забруднений мед, який непридатний для харчування людини. Разом з тим мед - основний продукт медоносних бджіл, який вони заготовляють для свого природного існування, і $є$ найбільш біологічно повноцінним для них кормом. Крім того, цукрово-медове тісто, з вмістом 16 \% такого меду, має питому активність ${ }^{137} \mathrm{Cs}$ в межах допустимих норм (Verbel'chuk et al., 2017).

Тому, мета досліджень - вивчити вплив весняної підгодівлі цукрово-медовим тістом на розвиток та медову продуктивність бджолиних сімей української породи в умовах чистих та радіоактивно забруднених природних угідь Житомирського Полісся.

\section{Матеріал і методи досліджень}

Для проведення досліджень створили контрольну групу, яка розташовувалася у с.Покостівка Житомирського району (ДП “Пулинський лісгосп АПК” Житомирської обласної ради), радіоактивно чиста зона та дослідну - с. Борутине Овруцького району (ДП “Овруцьке спеціалізоване лісове господарство”), друга зона радіоактивного забруднення. У даних населених пунктах розмістили по 8 бджолиних сімей, аналогів за силою, української породи, які утримувались в багатофункціональних вуликах. Для забезпечення інтенсивного приросту кількості бджіл у гніздах, всі сім’ї з 23 лютого почали підгодовувати цукрово-медовим тістом, виготовленим за рецептурою: цукрова пудра $-81 \%$, мед природних угідь - $16 \%$, вода $-3 \%$.

В склад медового тіста контрольної групи включали цукрову пудру, радіоактивно чистий мед та воду. В рецепті вуглеводистого корму дослідної групи використовували радіоактивно забруднений мед природних угідь. Питома активність ${ }^{137} \mathrm{Cs}$ у меду, складала 424 Бк/кг. Інгредієнти змішували та вимішували до тістоподібної маси впродовж 15-20 хв. Цукровомедове тісто в кількості 1 кг поміщали у пакети, у яких робили невеликі надрізи для доступу бджіл та розміщували на поверхні рамок обсиджених бджолами.

Один раз в тиждень проводили огляд 3 метою спостереження за споживанням даного продукту. Для оцінки відтворної здатності маток, визначення інтенсивності розвитку, стану бджолиних сімей проводили облік кількості розплоду в гніздах. Для цього використовували рамку-сітку, яка розділена на квадрати розміром $5 \times 5$ см. В одному квадраті рамки-сітки міститься 100 бджолиних комірок. На кожну сторону стільника прикладали рамку-сітку та підраховували кількість квадратів із розплодом. Загальну кількість квадратів зайнятих запечатаним та відкритим розплодом, множили на 100, щоб вирахувати кількість бджолиних комірок. Добову яйценосність матки визначали діленням суми комірок, зайнятих запечатаним та відкритим розплодом у сім'ї за один облік на 21 (період розвитку 
робочої бджоли) (Brovars'kyy, 2017). 323 лютого по 15 вересня проводили облік кількості відкритого, закритого розплодів та визначали яйценосність маток протягом сезону. За результатами зважувань центрифужного меду, визначили медову продуктивність даних сімей в весняно-літній та осінній сезони.

Вірогідність різниці між середньоарифметичними даними оцінювали за критеріями Стьюдента (Plohinskij, 1969).

\section{Результати та їх обговорення}

На продуктивність маток у весняний період найбільше впливають забезпеченість колоній натуральними кормами, погодні умови (температура, опади, во- логість), від яких залежить стан медоносної кормової бази та льотна діяльність бджіл. Тому, в таких умовах, для вирощування повноцінних молодих бджіл потрібен запас кормів вулику, що забезпечується весняною підгодівлею. Сильні сім’ї з молодою маткою і достатньо забезпечені кормами, значно легше протистоять несприятливим зовнішнім умовам, зокрема холоду, менше витрачають енергії й кормів (в розрахунку на 1 кг маси бджіл) для підтримки всередині свого клубу оптимальної температури (Polishchuk, 2001; Borst, 2012).

Облік кількості розплоду в гніздах сімей проводили через 21 день після початку періоду підгодівлі (табл. 1).

\section{Таблиця 1}

Кількість розплоду у бджолиних сім'ях протягом весняного періоду 2020 року, квадратів $(\mathrm{n}=8)$

\begin{tabular}{|c|c|c|c|c|}
\hline \multirow{2}{*}{ Показник } & \multicolumn{2}{|c|}{ Контрольна група } & \multicolumn{2}{|c|}{ Дослідна група } \\
\hline & відкритий & запечатаний & відкритий & запечатаний \\
\hline \multicolumn{5}{|c|}{16 березня } \\
\hline $\mathrm{M} \pm \mathrm{m}$ & $16,8 \pm 8,7$ & $49,5 \pm 4,2$ & $22,1 \pm 4,7$ & $61,2 \pm 6,9$ \\
\hline Lim & $14-19$ & $44-62$ & $20-27$ & $52-69$ \\
\hline $\mathrm{Cv}, \%$ & 10,9 & 11,4 & 14,0 & 13,4 \\
\hline \multicolumn{5}{|c|}{7 квітня } \\
\hline $\mathrm{M} \pm \mathrm{m}$ & $28,4 \pm 7,6$ & $142,2 \pm 5,3$ & $26,3 \pm 3,8$ & $129,8 \pm 6,8$ \\
\hline Lim & $22-46$ & $106-150$ & $20-27$ & $118-134$ \\
\hline $\mathrm{Cv}, \%$ & 12,0 & 11,0 & 12,8 & 14,0 \\
\hline \multicolumn{5}{|c|}{29 квітня } \\
\hline $\mathrm{M} \pm \mathrm{m}$ & $32,9 \pm 9,8$ & $164,6 \pm 6,9$ & $39,8 \pm 6,5$ & $197,5 \pm 5,6$ \\
\hline Lim & $18-41$ & $160-165$ & $32-43$ & $195-203$ \\
\hline $\mathrm{Cv}, \%$ & 13,9 & 11,9 & 14,1 & 12,2 \\
\hline \multicolumn{5}{|c|}{20 травня } \\
\hline $\mathrm{M} \pm \mathrm{m}$ & $43,8 \pm 3,7$ & $209,7 \pm 5,3$ & $43,7 \pm 3,9$ & $208,3 \pm 4,6$ \\
\hline Lim & $38-49$ & $208-214$ & $38-48$ & $206-211$ \\
\hline $\mathrm{Cv}, \%$ & 12,0 & 12,5 & 11,5 & 12,0 \\
\hline
\end{tabular}

Дослідження показали, що станом на 16 березня, кількість відкритого розплоду в бджолиних сім'ях контрольної групи в середньому становила 16,8 квадратів, що на 5,3 квадрати менше, порівняно $з$ дослідною групою. Кількість запечатаного розплоду у сім'ях першої групи знаходилась в межах від 44 до 62 квадратів, в той же час в дослідній - від 52 до 69 квадратів.

Станом на 7 квітня кількість відкритого розплоду контрольної групи збільшилась на 11,6 квадратів, що на 2,95 квадрати більше, порівняно 3 дослідною групою, кількість запечатаного розплоду в цій же групі в середньому складала 142,2 квадрат, тоді як в дослідній цей показник на 12,4 квадрати менший.

Середня кількість відкритого та запечатаного розплоду станом на початок весняного медозбору (29 квітня) в контрольній групі становила 32,9-164,6 квадрати, що на 6,9 - 33,1 квадрата менше порівняно 3 дослідною. Коефіцієнти варіації кількості відкритого розплоду у групах коливалися в межах 10,9-14,0 \%, зокрема меншою мінливістю характеризувалася дослідна група.

Отже, середня кількість відкритого розплоду у контрольній групі за період з 16 березня по 20 травня збільшилась 3 16,8 до 43,8 квадратів, а запечатаного 3 49,5 до 209,7 відповідно. Натомість, у дослідній групі кількість відкритого розплоду за даний період збільшилась з 22,1 до 43,7, закритого - з 61,2 до 208,3 квадрати. Вірогідної різниці між результатами розвитку бджолиних сімей не виявлено

Яйценосність - важливий показник стану гнізда та продуктивності матки. Показник дає можливість оцінити майбутню продуктивність сім'ї, хоча не завжди відображає кількість вирощених бджіл, так як у період їх розвитку частина яєць та личинок гине 3 різних причин. Для подальшого контролю за станом сімей впродовж сезону, здійснювали облік яйценосності маток у період 320 травня до 15 вересня через один місяць (табл.2). 
Таблиця 2

Яйценосність бджолиних маток за підгодівлі цукрово-медовим тістом, 2020 рік, яєць/добу $(\mathrm{n}=8)$

\begin{tabular}{|c|c|c|c|}
\hline Показник & Контрольна група & Дослідна група & \% до контролю \\
\hline \multicolumn{4}{|c|}{ Весняний період (20 травня) } \\
\hline $\mathrm{M} \pm \mathrm{m}$ & $1251,2 \pm 31,48$ & $1248,2 \pm 31,48$ & 99,3 \\
\hline Lim & $1148,0-1358,0$ & $1162,0-1444,0$ & $101,2-106.3$ \\
\hline $\mathrm{Cv}, \%$ & 12,9 & 12,0 & \\
\hline \multicolumn{4}{|c|}{ Літній період (20 червня) } \\
\hline $\mathrm{M} \pm \mathrm{m}$ & $1855,1 \pm 53,25$ & $1950,3 \pm 59,64$ & 105,1 \\
\hline Lim & $1752,0-1968,0$ & $1870,0-2026,0$ & $106,7-102,9$ \\
\hline $\mathrm{Cv}, \%$ & 10,9 & 11,0 & \\
\hline \multicolumn{4}{|c|}{ Літній період (20 серпня) } \\
\hline $\mathrm{M} \pm \mathrm{m}$ & $1241,1 \pm 36,82$ & $1245,3 \pm 22,08$ & 100,3 \\
\hline Lim & $1121,0-1359,0$ & $1070,0-1426,0$ & $95,5-104,9$ \\
\hline $\mathrm{Cv}, \%$ & 7,9 & 9,9 & \\
\hline \multicolumn{4}{|c|}{ Осінній період (15 вересня) } \\
\hline $\mathrm{M} \pm \mathrm{m}$ & $969,2 \pm 34,05$ & $961,8 \pm 26,46$ & 99,2 \\
\hline Lim & $869,0-1154,0$ & $826,0-1165,0$ & $95,0-100,9$ \\
\hline $\mathrm{Cv}, \%$ & 9,2 & 8,5 & \\
\hline
\end{tabular}

Середня яйценосність маток обох дослідних груп у весняний період суттєво не відрізнялась, а серед окремих сімей коливалась від 1148-1444 яєць на добу. Максимальні значення продуктивності маток отримані в літній період станом на 20 червня - 1968 яєць у сімях контрольної групи, та 2026 яєць у дослідній групі. В осінній період станом на 12 вересня, порівняно 3 весняним яйценосність маток контрольної групи зменшилась на 282 яйця у другій групі на $-286,4$ яєць на добу (табл. 2).
Зниження яйценосності у період головного медозбору обумовлено тим, що в цей період бджолина сім'я, зазвичай, витрачає свої сили на заготівлю та переробку нектару і пилку. Через це бджоли обмежують матку у відкладанні яєць.

Медову продуктивність визначали за валовим виходом центрифужного меду і того, що залишився в гнізді, як кормовий запас за результатами двох відкачувань протягом 20-23 червня, після цвітіння весняних природних медоносів і 25-27 серпня, після цвітіння літньо-осінніх (табл. 3).

Таблиця 3

Медова продуктивність бджолиних сімей при використанні природних фітоценозів, кг

\begin{tabular}{cccc}
\hline Показник & контрольна група & дослідна група & \% до контролю \\
\hline & & Весняно-літній період & 109,3 \\
$\mathrm{M} \pm \mathrm{m}$ & $15,1 \pm 0,58$ & $16,5 \pm 0,65$ & $115,1-104,7$ \\
$\mathrm{Lim}$ & $13,2-17,0$ & $15,2-17,8$ & - \\
$\mathrm{Cv}, \%$ & 7,7 & 6,1 & 107,7 \\
\hline & & Літньо-осінній період & $116,2-101,1$ \\
\hline $\mathrm{Lim}$ & $15,6 \pm 0,54$ & $16,8 \pm 0,61 *$ & - \\
$\mathrm{Cv}, \%$ & $13,6-17,6$ & $15,8-17,8$ & 6,4 \\
\hline
\end{tabular}

Примітка. ${ }^{*}-\mathrm{P} \leq 0,05$

Медова продуктивність бджолиних сімей обох груп на медозборі з природних угідь особливо не відрізнялась і в середньому у весняно-літній період становила 15,1-16,5 кг, у літньо - осінній 15,6-16,8 кг, при цьому мінливість ознаки всіх груп була низькою та коливалась від 6,1-7,7 \% протягом всього сезону. За весь медоносний сезон 2020 року від бджолиних сімей контрольної групи отримано 30,7 кг меду на сім'ю, що на 7,7 \% менше, порівняно 3 дослідною. Вірогідна різниця між даними показниками становить $(\mathrm{P} \leq 0,05)$.

Як видно з даних таблиці 3 медова продуктивність бджолиних сімей на медозборі з природних угідь мала вірогідну різницю між показниками контрольної та дослідної груп $(\mathrm{P} \leq 0,05)$. Можлива причина такого результату - більша різноманітність природних фіто- ценозів, які забезпечують фактичний медовий запас місцевості радіоактивно забрудненого регіону.

За результатами осінньої ревізії бджолиних сімей обох груп визначили, що станом на 25 серпня, за силою вони були практично однакові і мали 8,6-8,9 вуличок бджіл (табл. 4), та приблизно 8 кг запасу кормового меду. Наукові дослідження підтверджують, що інтенсивний медозбір наприклад із соняшника, негативно впливає на силу бджолиних сімей, вони розвиваються повільніше і кількість особин у гніздах зменшується. Такі сім'ї не зможуть повноцінно відновитись до нового медового сезону без відповідних технологічних заходів, наприклад, підсилення бджолиними відводками або роями та різних видів підгодівлі в осінній період (Polishchuk, 2014) 
Таблиця 4

Стан бджолиних сімей після закінчення медозбору з природніх угідь $(\mathrm{n}=8)$

\begin{tabular}{|c|c|c|c|c|}
\hline \multirow{2}{*}{ Показник } & \multirow{2}{*}{ медовий запас, кг } & \multicolumn{2}{|c|}{ кількість розплоду, квадратів } & \multirow{2}{*}{$\begin{array}{c}\text { сила бджолиних сімей, } \\
\text { вуличок }\end{array}$} \\
\hline & & відкритого & запечатаного & \\
\hline \multicolumn{5}{|c|}{ Контрольна група } \\
\hline $\mathrm{M} \pm \mathrm{m}$ & $8,7 \pm 0,24$ & $24,6 \pm 3,41$ & $123,3 \pm 6,81$ & $8,6 \pm 0,35$ \\
\hline Lim & $7,9-9,4$ & $22,6-26,1$ & $119,5-129,3$ & 7,9-9,1 \\
\hline $\mathrm{Cv}, \%$ & 7,1 & 10,1 & 7,1 & 9,1 \\
\hline \multicolumn{5}{|c|}{ Дослідна група } \\
\hline $\mathrm{M} \pm \mathrm{m}$ & $8,4 \pm 0,28$ & $23,5 \pm 2,91$ & $119,6 \pm 5,98$ & $8,9 \pm 0,28$ \\
\hline Lim & $7,2-9,1$ & $21,9-24,6$ & $117,8-125,3$ & $8,1-9,4$ \\
\hline $\mathrm{Cv}, \%$ & 8,9 & 11,2 & 8,1 & 9,5 \\
\hline
\end{tabular}

Але наші дослідження показали, що після закінчення медозбору з природних угідь, бджолині сім'ї української породи, як у радіоактивно забрудненій так і чистій зоні, мали середню силу.

\section{Висновки}

Дослідження показали, що підгодівля бджолиних сімей цукрово-медовим тістом 3 додаванням радіоактивно забрудненого меду, порівняно з використанням чистого меду, не чинить негативного впливу на їх розвиток, проте, у весняний період, такий вид підгодівлі сприяє рівномірному та інтенсивному вирощуванню розплоду.

Навесні такі сім’ї швидко розвиваються, вирощують до головного медозбору велику кількість робочої бджоли, що дає можливіть збільшити виробництво продуктів бджільництва.

\section{References}

Abdulaziz, S. (2020). Differential Foraging of Indigenous and Exotic Honeybee (Apis mellifera L.) Races on Nectar-Rich Flow in a Subtropical Ecosystem King Saud University, Saudi Arabia.Insects, 11(4), 254. doi: 10.3390/insects11040254.

Andjelkovic, B, Jevtic, G, Mladenovic, M, \& Petrovic, M. (2011). Influence of spring feed on the strength of honey bee colonies during spring developmen. Biotechnology in Animal Husbandry, 27(4), 17571760. doi: 10.2298/BAH1104757A.

Borst, P. L. (2012). The History of Bee Breeding. Am Bee J., 152(7), 679-683.

Brodschneider, R., \& Crailsheim, K. (2010). Nutrition and health in honey bees. Apidologie, 41, 278-294. doi: 10.1051/apido/2010012.

Brovarskyi, V. D., \& Bahrii, I. H. (1995). Rozvedennia ta utrymannia bdzhil. Kyiv: Urozhai (in Ukrainian).

Brovars'kyy, V. D. (2017). Metodyka doslidzhen'u bdzhil'nytstvi. Kyyiv (in Ukrainian).

Byel's'ka, O. V. (2020). Suchasni problemy funktsionuvannya Polis'koho pryrodnoho zapovidnyka v umovakh zminy klimatu. Zhytomyr (in Ukrainian).
Di Pasquale, G., Salignon, M., Le Conte, Y., Belzunces, L. P., Decourtye A., Kretzschmar, A., \& Alaux, C. (2013). Influence of pollen nutrition on honey bee health: Do pollen quality and diversity matter? PLoS ONE, 8(8), e72016. doi: 10.1371/journal.pone.0072016.

Khoury, D. S., Barron, A. B., \& Myerscough, M. R. (2013). Modelling Food and Population Dynamics in Honey Bee Colonies. PLoS ONE, 8(5), e59084. doi: 10.1371/journal.pone.0059084.

Mattila, H., \& Otis, G. (2006). Influence of pollen diet in spring on development of honey bee (Hymenoptera: Apidae) colonies J Econ Entomol., 99(3), 604-613. doi: 10.1603/0022-0493-99.3.604.

Pankiw, T., Tarpy, D. R., Page, R. E. (2002). Genotype and rearing environment affect honeybee perception and foraging behaviour. Anim. Behav, 64(4), 663672. doi: 10.1006/anbe.2002.3096.

Papchenko, O. V. (2013). Rozvytok bdzholynykh simey za riznykh sposobiv yikh utrymannya $\mathrm{v}$ umovakh produktyvnykh medozboriv. Visnyk Luhans'koho natsional'noho ahrarnoho universytetu: nauk.-teor. zb., 18(2(31), 119-123 (in Ukrainian).

Plohinskij, N. A. (1969). Rukovodstvo po biometrii dlja zootehnikov. M.: Kolos, 25-27 (in Russian).

Polishchuk, V. (2014). Vplyv bdzholynykh matok riznoho viku na rozvytok i produktyvnist' bdzholynykh simey .Tvarynnytstvo Ukrayiny, 2, 7-10 (in Ukrainian).

Polishchuk, V. P. (2001). Bdzhil'nytstvo. Kyyiv. Vyshcha shkola (in Ukrainian).

Puškadija, Z., Biber, L., \& Kovačić, M. (2017). Late winter feeding stimulates rapid spring development of carniolan honey bee colonies. Apis Mellifera carnica Poljoprivreda, 23(2),73-76. doi: 10.18047/poljo.23.2.11.

Sichenko, O. M., Kryvyi, M. M., \& Dikhtiar O. O. (2021). Comparative evaluation of honey stok of natural phytocenoses for bee families of Ukrainian Polisya. Bulletin of Sumy National Agrarian University. The series: Livestock, 3(46), 84-89. doi: 10.32845/bsnau.lvst.2021.3.11 (in Ukrainian).

Verbel'chuk, S. P., Kryvyy, M. M., Vasenkov, H. I., Verbel'chuk, T. V., \& Dikhtyar, O. O. (2017). Biotsenozy lisu ta yikh medova produktyvnist' na Polissi Zhytomyrshchyny. Ahrarna nauka ta kharchovi tekhnolohiyi, (3), 129-140. (in Ukrainian). 